\title{
MENTAL SURGERY: ANOTHER LOOK AT THE IDENTITY PROBLEM, A CONVERSATION WITH JONATHAN CHIMAKONAM
}

DOI: http://dx.doi.org/10.4314/ft.v4i1.6

\author{
Aribiah David ATTOE \\ Department of Philosophy, University of Calabar, Nigeria
}

The question of what constitutes the personal identity of an individual has been pondered upon by many philosophers and Jonathan Chimakonam is one of such philosophers. His paper entitled "Mental Surgery: Another look at the Identity Problem" addresses this issue headlong and his conclusions are fascinating to say the least. Chimakonam in his essay adopts a sociological approach to the identity problem. For him, personal identity is basically a social property and a sociological concept $(2011,201)$. He also goes on to suggest that personal identity lies in the physical body and not in any metaphysical entity, soul or mind. Indeed, Chimakonam goes further to deny the existence of an independent spiritual mind or soul, which is the basis of the Cartesian mind-body dualism. What is implied here is that without the body, personal identity is inconceivable. It also implies that although personal identity is resident in the physical body of an individual, it must also be perceived and recognised by other individuals within the society such a body finds itself. To fortify this line of thought, Chimakonam articulates a thought experiment which describes a mental surgery in which the "minds" of two individuals (a dying Professor C. S. Momoh and Jonathan Chimakonam) are interchanged and with no short term memory, the mind of the professor, now inhabiting the body of Chimakonam, though bemused by the change in his bodily appearance, begins to gradually accept a new identity (that of Chimakonam) based on the insistence of those around him, which invariably alludes to the view that personal identity is determined by the opinions of others and thus, a sociological property $(2011,197$ 200). Peter Bisong, in a response to Chimakonam's paper, argues that the spiritual soul/consciousness is the primary criterion of personal identity. He disputes Chimakonam's sociological stance by making us aware of the fact that a change of society by a subject may present differing views on the personal identity of that subject and as such, the individual's identity becomes contradictory (2014, 60-63).

Chimakonam's view point may be agreeable to some but as I shall argue, it misses the mark on certain points. It fails to recognise that the sociological influence on the concept of personal identity is based both on a false premise and on an invalid argument, it fails to recognise the role of the "self" in the concept of personal identity and finally, it fails to recognise the fact that the concept of personal identity is nothing more than a necessary illusion.

D The diachronic nature of the human body as well as the human psyche ofcannot be overlooked and from a strictly logical standpoint, the idea of "continuity"

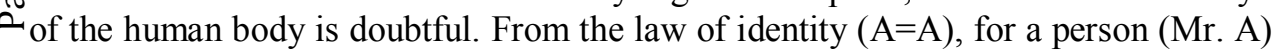
to be considered the same as the person that existed yesterday, he must possess the 
same properties with the individual that lived a day before. This is however impossible because a single change in cell development, body mass, or even a change in thinking patterns suggest a change in property and a change in property implies a change in identity and as such to claim sameness or continuity is logically absurd.

Individual

Individual with future changes

Concept of continuity:

$$
\begin{aligned}
& =\mathrm{A} \\
& =\sim \mathrm{A} \\
& \mathrm{A}=\sim \mathrm{A} \text { (Logical Absurdity) }
\end{aligned}
$$

Though this is true, the difficulty in keeping track of constant bodily changes and giving new identity as these changes occur is not lost on the brain. In order to bypass this near-impossible task, the brain assumes sameness of the body and based on this false but necessary premise attaches an "identity" to a human body. Thus the exclamatory phrase "I cannot believe this is you...!" is uttered when our brains encounter changes in an individual, which are too drastic to ignore because the brain assumes a false representation of sameness as reality.

A common (mis)conception Chimakonam also falls prey to is the view that the existence of a thing resides in the perception of that thing by others which was brought about by the Berkeley's maxim "to be is to be perceived". This view is at best sensational, with no logical connection behind it. To be is simply to exist and to exist does not depend on another being. If I exist as the only being in the world, I do not need another human being to perceive my body, bec ause whether that individual perceives me or not, insofar as I exist, my body would exist regardless. If this is true, then it would be odd to suggest, as Chimakonam submits, that without the society, there is no person and that for the "self" to be meaningful, it must make sense to others $(2011,201)$. The awareness one has of his existence directly correlates with his feelings of identity i.e. his recognition of his "self" and such feelings are independent of societal influences as well as communal existen ce. If this is true, then the idea of personal identity as a social property would seem far-fetched.

To sum up this conversation, this paper argues that our idea of the "self" or personal identity, is nothing more than illusion which we cannot help but have. Like the mirage of water on the road which we cannot help but have because of the sun's intensity, the illusion of personal identity is due to our brains interpretation of its ability to understand reality. In understanding consciousness (the foundation of our understanding of the self) we discover that consciousness is nothing more than the ability to perceive, understand and give meaning to that which is perceived as well as our emotional states, etc., (CHURCHLAND 2002, 133). In a bid to give meaning to this process of consciousness - a sort of meta-interpretation - the brain gives us the illusion of a self distinct from itself and it is to this illusory self that most individuals offeel their personal identity resides. 
Filosofia Theoretica: Journal of African Philosophy, Culture and Religions

\section{Relevant Literature}

1. BISONG, Peter. “Jonathan O. Chimakonam's Concept of Personal Identity: A Critical Reflection [Filosofia Theoretica], pp50-66, Vol 3., No 1., January-June. 2014. Paperback.

2. CHURCHLAND, Patricia. [Brain-Wise: Studies in Neurophilosophy], 2002. MIT Press: Massachusetts. Paperback

3. OKEKE, Jonathan Chimakonam. "Mental Surgery: Another Look at the Identity Problem" [Filosofia Theoretica], pp195-208, Vol 1., No 1., Dec. 2011. Paperback. 